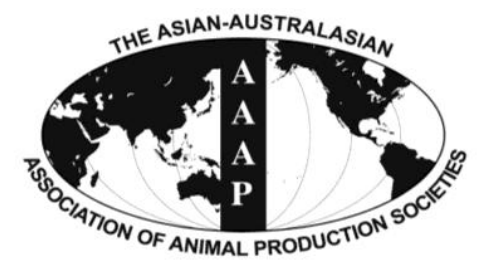

Asian Australas. J. Anim. Sci.

Vol. 26, No. 6 : 874-878 June 2013

http://dx.doi.org/10.5713/ajas.2012.12652

www.ajas.info

pISSN 1011-2367 elSSN 1976-5517

\title{
Changes in Blood Constituents of Rabbits Subjected to Transportation under Hot, Humid Tropical Conditions
}

\author{
K. Nakyinsige ${ }^{1,6}$, A. Q. Sazili ${ }^{1,2, *}$, Z. A. Aghwan ${ }^{2,7}$, I. Zulkifli ${ }^{1,3}$, Y. M. Goh ${ }^{4}$ and A. B. Fatimah ${ }^{5}$ \\ ${ }^{1}$ Halal Products Research Institute, Universiti Putra Malaysia, 43400 UPM Serdang, Selangor Darul Ehsan, Malaysia
}

\begin{abstract}
Unlike Europe (particularly, Italy and Spain), where a number of studies have been conducted on the stressful effects of transport on rabbit welfare, few studies have been conducted on transportation of rabbits under hot, humid tropical conditions experienced in countries like Malaysia. We studied the effects of transportation in hot humid tropical conditions of Malaysia on physiometabolic changes in New Zealand white rabbits. Eighty experimental animals were divided into two groups of 40 bucks each and transported for either 3 or $1 \mathrm{~h}$. Transportation caused a significant upsurge of aspartate aminotransferase, alanine aminotransferase and creatine kinase activities $(\mathrm{p}<0.001)$ though did not significantly affect lactate dehydrogenase $(\mathrm{LDH})$ activity $(\mathrm{p}=0.0706)$. Both transportation periods caused elevation in plasma glucose levels, lactic acidosis and dehydration as evidenced through elevated packed cell volume and plasma protein concentration. It was concluded that regardless of the duration, transport of rabbits under hot humid tropical conditions, resulted in heat distress since the rabbits showed hyperglycemia, hypercalcemia, lactacidemia, lymphocytopenia, dehydration and increase in blood enzyme activities. (Key Words: Welfare, Rabbits, Transport, Stress)
\end{abstract}

\section{INTRODUCTION}

The intensity and specialization of livestock production in particular areas and the demand for livestock to be marketed and slaughtered in other areas where they are not produced have necessitated transportation of food animals all over the world (Minka and Ayo, 2009). Rabbits (Oryctolagus cuniculus) are bred in both tropic and subtropical regions of the world (Sabuncuoglu et al., 2011)

\footnotetext{
* Corresponding Author: Awis Qurni Sazili. Tel: +60389474870, Fax: +60389381024, E-mail: awisqurni@gmail.com

2 Department of Animal Science, Faculty of Agriculture, Universiti Putra Malaysia, 43400 UPM Serdang, Selangor Darul Ehsan, Malaysia.

${ }^{3}$ Institute of Tropical Agriculture, Universiti Putra Malaysia, 43400 UPM Serdang, Selangor Darul Ehsan, Malaysia.

${ }^{4}$ Department of Preclinical Medicine, Faculty of Veterinary Medicine, Universiti Putra Malaysia, 43400 UPM Serdang, Selangor Darul Ehsan, Malaysia.

${ }^{5}$ Department of Food Science, Faculty of Food Science and Technology, Universiti Putra Malaysia, 43400 UPM Serdang, Selangor Darul Ehsan, Malaysia.

${ }^{6}$ Department of Food Science and Nutrition, Islamic University In Uganda, 2555, Mbale, Uganda.

${ }^{7}$ Department of Animal Science, University of Mosul, Mosul, Iraq.

Submitted Nov. 21, 2012; Accepted Feb. 17, 2013; Revised Mar. 3, 2013
}

and may be transported for a variety of reasons including breeding, use as pets, biomedical purposes, and slaughter. During transportation, rabbits may be exposed to various types of stressors including physical (such as high ambient temperature, vibration and changes in acceleration), psychological (such as confinement, noise and crowding during loading onto trucks, transport and marketing or at the abattoir prior to sticking) and physiological (e.g. water and food deprivation). In addition, stress may arise from bruises, injuries, starvation and tiredness.

Animals normally respond to stimuli (stressors) with a pattern of behavioural, endocrine, neural, immune, hematologic and metabolic changes designed to restore homeostasis in order to be adaptive or to promote survival (Knowles and Warriss, 2000; Warriss, 2000; Muir, 2004). Consequently, scientists have used physiological and behavioural alterations to measure and monitor animal welfare. These stressors can trigger several physiological responses, particularly increased concentrations of primary mediators (stress-related hormones; glucocorticoids, catecholamines and beta-endorphins) (von Borell, 2001; Terlouw et al., 2008), which in turn leads to changes in biochemical and haematological components (Nemec Svete et al., 2012). Transportation induces changes in the blood composition, electrolytes, hormones, metabolites and enzymes (Fazio and Ferlazzo, 2003; Minka and Ayo, 2009). 
Transport is an important critical point in meat production systems; whose time and/or mismanagement pose potential risks to not only animal welfare but also meat quality.

In Europe, particularly Italy and Spain, a number of studies on the stressful effects of transport prior to slaughter of rabbits have been conducted. Conversely, in Asia and Malaysia in particular, hardly has any study been conducted on transportation of rabbits. Heat stress is a problem of great concern that is commonly encountered during road transportation of farm animals (Zulkifli et al., 2010a; b). Literature shows that there exist differences in the effects of transport of rabbits during summer and winter (De la Fuente et al., 2004; Lambertini et al., 2006; Mazzone et al., 2010). However there is no literature on the influence of transportation of rabbits under the hot, humid tropical conditions. Therefore, the aim of this study was to evaluate, under the hot, humid tropical conditions of Malaysia, the effect of road transport duration on the welfare of rabbits as assessed through the concentrations of some blood constituents.

\section{MATERIALS AND METHODS}

This study was conducted following the animal ethics guidelines of the Research Policy of Universiti Putra Malaysia.

\section{Animals and experimental design}

A total of 80 male New Zealand white rabbits of average live weight $2,008 \pm 216 \mathrm{~g}$ raised under the same conditions and fed the same type of feed were used as experimental animals. The trial was conducted on two consecutive days with an average environmental temperature of $28^{\circ} \mathrm{C}$ and $76 \%$ relative humidity. To determine the basal levels of the parameters analyzed; before loading the animals, blood samples were collected from the 10 randomly chosen rabbits assigned as a control group (T1). The rabbits were divided into two groups of 40 each. Group one was transported for $1 \mathrm{~h}$ during which an average distance of $55 \mathrm{~km}$ was covered (T2) while Group two was transported for $3 \mathrm{~h}$ for an average distance of 126 km (T3). The rabbits were carefully loaded into plastic cages of $90 \times 40 \times 25 \mathrm{~cm}$ (length $\times$ width $\times$ height). Each cage was used to transport 5 rabbits. An open truck (to mimic commercial conditions) was used for transport. On each day, the journey started at 10:00 am.

\section{Blood sampling}

At each sampling time, individual rabbits were comfortably restrained in a commercial rabbit restrainer and $5 \mathrm{ml}$ of blood were collected from the ear vein of 10 randomly chosen rabbits using 21 gauge needles. The blood samples were collected in Lithium Heparin tubes, temporarily stored in crushed ice and transported to the Hematology Laboratory, Faculty of Veterinary Medicine, Universiti Putra Malaysia within less than two hours.

\section{Blood analysis}

Alanine aminotransferase (ALT), aspartate aminotransferase (AST), lactate dehydrogenase (LDH), creatine kinase $(\mathrm{CK})$, glucose, lactate, urea, total protein and calcium were determined using an automatic analyzer (Automatic analyzer 902, Hitachi, Germany). Total hemogram (packed cell volume (PCV), hemoglobin, red blood cells (RBC), white blood cells (WBC), and lymphocytes) was determined using an automatic hematology analyzer (CELL DYN ${ }^{\circledR} 3700$, Abbot, USA) using Veterinary Package soft ware.

\section{Data analysis}

The experiment was of a completely randomized design (CRD). The experimental unit considered for all variables measured during the study was the rabbit. All analyses were performed using the GLM procedure of Statistical Analysis System package (SAS) Version 9.2 software (Statistical Analysis System, SAS Institute Inc., Cary, NC, USA) and statistical significance was set at $\mathrm{p}<0.05$. Data were subjected to one-way analysis of variance (ANOVA) using a model that included treatment and animal as possible source of variation. Duncan multiple range test was used to test the significance of variance between the means of the studied parameters.

\section{RESULTS AND DISCUSSION}

The mean values of biochemical variables that were studied (Table 1) show that the variables considered were significantly influenced by transport except LDH ( $\mathrm{p}=$ 0.0706). The activities of enzymes ALT $(\mathrm{p}<0.001)$, AST $(\mathrm{p}<0.001)$ and CK $(\mathrm{p}<0.001)$ significantly increased in all animals after transport. There was an increment in the levels of glucose, lactate, total protein, calcium and urea $(p<0.001)$. The mean values of hematological variables are shown in Table 2. In this study, both transportation periods have resulted in lymphocytopenia in rabbits. Besides, WBC and RBC counts, hemoglobin concentration, hematocrit and packed cell volume were significantly increased with transport.

\section{Effect of transportation biochemical parameters of rabbits}

Blood glucose was significantly higher in animals that were transported for $3 \mathrm{~h}$ (T3) than in those which were transported for $1 \mathrm{~h}$ (T2) or in the control (T1) group (7.24 vs 6.05 or $4.99 \mathrm{mmol} / \mathrm{L}$; $\mathrm{p}<0.001)$. Experimental results from elsewhere have also shown increment in glucose 
Table 1. Differences in blood biochemical parameters of rabbits subjected to different transportation durations

\begin{tabular}{|c|c|c|c|c|c|c|}
\hline Parameter & $\mathrm{T} 1$ & $\mathrm{~T} 2$ & $\mathrm{~T} 3$ & SEM & $\mathrm{p}$ value & $\begin{array}{c}\text { Normal physiological } \\
\text { range }\end{array}$ \\
\hline$\overline{\text { Glucose }(\mathrm{mmol} / \mathrm{L})}$ & $4.99^{\mathrm{c}}$ & $6.05^{\mathrm{b}}$ & $7.24^{\mathrm{a}}$ & 0.09 & $<0.0001$ & $75-155 \mathrm{mg} / \mathrm{dl} *$ \\
\hline Lactate $(\mathrm{mmol} / \mathrm{L})$ & $7.74^{\mathrm{c}}$ & $9.13^{\mathrm{b}}$ & $13.10^{\mathrm{a}}$ & 0.19 & $<0.0001$ & \\
\hline Total protein $(\mathrm{g} / \mathrm{L})$ & $64.99^{c}$ & $67.80^{\mathrm{b}}$ & $73.87^{\mathrm{a}}$ & 0.68 & $<0.0001$ & $5.4-7.5 \mathrm{~g} / \mathrm{dl}^{*}$ \\
\hline Calcium (mmol/L) & $2.92^{\mathrm{c}}$ & $3.06^{\mathrm{b}}$ & $3.30^{\mathrm{a}}$ & 0.02 & $<0.0001$ & $11-14 \mathrm{mg} / \mathrm{dl} *$ \\
\hline Urea $(\mu \mathrm{mol} / \mathrm{L})$ & $127.30^{c}$ & $146.40^{\mathrm{b}}$ & $155.50^{\mathrm{a}}$ & 1.15 & $<0.0001$ & $20-45 \mathrm{mg} / \mathrm{dl} *$ \\
\hline Creatine kinase (U/L) & $599.90^{c}$ & $681.80^{\mathrm{b}}$ & $758.50^{\mathrm{a}}$ & 11.84 & $<0.0001$ & $140-372 *$ \\
\hline Lactate dehydrogenase (U/L) & $309.70^{\mathrm{b}}$ & $310.30^{\mathrm{ba}}$ & $313.50^{\mathrm{a}}$ & 1.19 & 0.0706 & \\
\hline Alanine aminotransferase (U/L) & $44.71^{\mathrm{c}}$ & $51.93^{\mathrm{b}}$ & $56.32^{\mathrm{a}}$ & 0.70 & $<0.0001$ & $45-80 *$ \\
\hline Aspartate aminotransferase (U/L) & $23.90^{\mathrm{c}}$ & $25.22^{\mathrm{b}}$ & $29.47^{\mathrm{a}}$ & 0.42 & $<0.0001$ & $35-130 *$ \\
\hline
\end{tabular}

T1 = Control (basal blood parameters before transportation). T2 = Animals transported for one hour. T3 = Animals transported for three hours.

${ }^{a, b, c}$ Least square mean with different superscripts within the same row show significant differences among treatments $(\mathrm{p}<0.05)$.

* A. Melillo (2007). Rabbit Clinical Pathology. Journal of Exotic Pet Medicine, 16:135-145.

levels after transportation of rabbits (De la Fuente et al., 2004; Lambertini et al., 2006; Liste et al., 2008). The involvement of glucose in energy metabolism during stressful situations has resulted in its quantification becoming a useful tool for assessing stress. Glucose concentration increases through increased rate of glycogenolysis and gluconeogenesis associated with the increase in catecholamine and glucocorticoids, which are released during stressful situations (Shaw and Tume, 1992).

Blood lactate concentration was found to be significantly increased after transport. When the circulation system can longer supply the working muscle with adequate oxygen, there occurs a shift to anaerobic oxidation; the consequence of which is an increment in blood lactate concentration. Blood lactate concentration can also increase due to the work of panting (Garbus et al., 1967). Since rabbits do not sweat, when they are exposed to high ambient temperature, particularly above 25 to $30^{\circ} \mathrm{C}$, they try to balance the excessive heat load through different means including panting. Panting is an inefficient mode of heat dissipation whose prolongation can lead to metabolic alkalosis (EFSA, 2011). Marai and Rashwan (2004) showed that the optimal climatic conditions for rabbits would be temperatures 13 to $20^{\circ} \mathrm{C}$ (average $15^{\circ} \mathrm{C}$ ) and relative humidity 55 to $65 \%$ (average 60\%). In our study, the average temperature during the journeys was $28^{\circ} \mathrm{C}$ with a relative humidity of $76 \%$. Thermal stress experienced during transport is a crucial factor in rabbit welfare. However, few studies have focused on this research area, all of which are from the Mediterranean and hardly has any study been done under hot humid tropical conditions.

There was significant increase in the activities of enzymes ALT, AST and CK in all rabbits after transport $(p<0.001)$. Serum enzyme levels are indicators of tissue damage. Elevated levels of ALT and AST are indicative of hepatopathy, muscular dystrophy and damage to internal organs. Increased level of ALT in serum is indicative of damage to liver parenchyma. Creatine kinase is a very sensitive enzyme during extraneous activity, which catalyses the conversion of creatine to phosphocreatine for energy reservoir in tissues, thus elevated CK activity can be used as an index of cell muscle damage and muscle fatigue (EFSA, 2004). CK has proved to be the most sensitive parameter of tissue damage. High levels of CK are indicative of skeletal and cardiac muscle damage. Increment in blood activity of CK is likely to be associated with changes in cell membrane permeability caused by changes in tissue temperature (Manjoo et al., 1985).

Table 2. Differences in hematological parameters of rabbits subjected to different transportation durations

\begin{tabular}{|c|c|c|c|c|c|c|}
\hline Parameter & $\mathrm{T} 1$ & $\mathrm{~T} 2$ & $\mathrm{~T} 3$ & SEM & $\mathrm{p}$ value & $\begin{array}{l}\text { Normal physiological } \\
\text { range }\end{array}$ \\
\hline White blood cells $\left(\times 10^{9} / \mathrm{L}\right)$ & $5.108^{c}$ & $6.567^{\mathrm{b}}$ & $7.625^{\mathrm{a}}$ & 0.055 & $<0.0001$ & $5-12.5^{*}$ \\
\hline Lymphocytes $\left(\times 10^{9} / \mathrm{L}\right)$ & $4.073^{\mathrm{a}}$ & $2.080^{\mathrm{b}}$ & $1.780^{\mathrm{c}}$ & 0.030 & $<0.0001$ & $1.6-10.6^{*}$ \\
\hline Red blood cells $\left(\times 10^{12} / \mathrm{L}\right)$ & $4.701^{\mathrm{c}}$ & $5.040^{\mathrm{b}}$ & $5.314^{\mathrm{a}}$ & 0.028 & $<0.0001$ & $5-8^{*}$ \\
\hline Packed cell volume (L/L) & $0.222^{\mathrm{c}}$ & $0.273^{\mathrm{b}}$ & $0.326^{\mathrm{a}}$ & 0.006 & $<0.0001$ & $33-50 \% *$ \\
\hline Hematocrit (\%) & $28.281^{\mathrm{c}}$ & $30.843^{\mathrm{b}}$ & $33.114^{\mathrm{a}}$ & 0.342 & $<0.0001$ & $33-50 \% *$ \\
\hline Hemoglobin $(g / L)$ & $94.270^{c}$ & $102.810^{\mathrm{b}}$ & $110.380^{\mathrm{a}}$ & 1.027 & $<0.0001$ & $10-17 \times 10 \mathrm{~g} / \mathrm{L} *$ \\
\hline
\end{tabular}

$\mathrm{T} 1=$ Control ((basal blood parameters before transportation). T2 = Animals transported for one hour. T3 = Animals transported for three hours.

${ }_{\mathrm{a}, \mathrm{b}, \mathrm{c}}$ Least square mean with different superscripts in the same row show significant differences among treatments $(\mathrm{p}<0.05)$.

* Merck Sharp \& Dohme Corporation (2011). The Merck Veterinary Manual. Retrieved 19/02/2013 from http://www.merckvetmanual.com/mvm/ $\mathrm{htm} / \mathrm{bc} /$ tref6.htm 
Lactate dehydrogenase is a liver enzyme whose activity changes in response to factors associated with stress and muscle fatigue (weariness). In the present experiment, LDH activity after transport did not differ from values detected at the farm $(\mathrm{p}=0.0706)$. This could be attributed to the fact that the weariness suffered by the rabbits during transport was not too severe to cause an upsurge in this liver enzyme activity. This is in agreement with the results of Mazzone et al. (2010) who reported no variation of LDH in rabbits after transport.

Urea level was significantly higher in rabbits that were transported for $3 \mathrm{~h}$ than in those which were transported for $1 \mathrm{~h}$ or in the control group (156 vs 146 or $127 \mathrm{mmol} / \mathrm{L}$; $\mathrm{p}<0.001)$. Elevation of urea level after transport under hot, humid tropical conditions could be a sign of heat stress. Under heat stress, animals experience abnormal renal function due to change in the power of selective reabsorption of kidney tubules leading to the retention of urea within the blood (Abdelatif and Modawi, 1994). Elevated blood urea levels could also be attributed to dehydration since rabbits have a limited ability to concentrate urine and only a few hours without drinking may be enough to cause azotemia (Melillo, 2007).

\section{Effect of transportation on rabbit haematological parameters}

Due to factors like time without water, increased respiration rates and urinary water loss, transport often causes dehydration. Dehydration and hemoconcentration of rabbits after transport was evidenced through elevated PCV and plasma protein concentration. PCV increased significantly after transport and this is in contrast with Mazzone et al. (2010) and Listle et al. (2008) who did not find any variation of PCV of rabbits after transport. Decreased intake of water during transportation has the direct effect of decreasing intracellular and extracellular fluid volumes (Knowles and Warris, 2000). Consequently, plasma osmolality, total plasma protein and packed-cell volume increase (Broom, 2003). There exist differences between small animals like rabbits and large animals in energy expenditures. Small animals require more calories per unit of body mass and become dehydrated more quickly than larger animals due to large surface area to volume ration. For this reason, compared to larger animals, rabbits may become stressed faster and more severely by food or water deprivation during transportation. Sabuncuoglu et al. (2011) reported that the pre-slaughter environment is a potential stressor for rabbits. Due to socio-economic and cultural reasons, rabbit meat is still considered a niche product in Malaysia despite the steady increase in rabbit production. Several problems regarding rabbit welfare still need to be addressed. Hence, the need for local research to support regulations on rabbit transport.
In this study, the immune system of rabbits was affected by transport. Both transportation periods resulted in increased White blood cell (WBC) count. The upsurge in the number of white cells in the blood (leukocytosis) is likely to have been caused by the acute stress suffered by the rabbits during transport. It is well known that leukocytosis in acutely stressed animals is caused by the endogenous release of corticosteroids or epinephrine (Pérez et al., 2002). Lymphocytopenia was also observed in the rabbits after transport $\left(4.07 \times 10^{9} / \mathrm{L}\right.$ in $\mathrm{T} 1$ vs 2.08 and 1.78 $\times 10^{9} / \mathrm{L}$ in $\mathrm{T} 2$ and $\mathrm{T} 3$, respectively). This observation is in agreement with the findings of Vignola et al. (2008) who also reported lymphocytopenia in rabbits after transport. Despite the transport duration, an upsurge was noticed in red blood cell count.

\section{CONCLUSION}

It was concluded that regardless of the duration, transport of rabbits under hot humid tropical conditions, resulted in heat distress since the rabbits showed hyperglycemia, hypercalcemia, lactacidemia, lymphocytopenia, dehydration and increase in blood enzyme activities.

\section{ACKNOWLEDGEMENTS}

The first author is greatly indebted to Islamic Development Bank Group (IDB) for the scholarship. The authors greatly acknowledge Universiti Putra Malaysia for the funding through Research University Grant Scheme (Project No.: 02-02-12-1713RU).

\section{REFERENCES}

Abdelatif, A. M. and S. M. Modawi. 1994. Effects of hyperthermia on blood constituents in the domestic rabbits (Lepus cuniculus). J. Therm. Biol. 19:357-363.

Broom, D. M. 2003. Transport stress in cattle and sheep with details of physiological, ethological and other indicators. Dtsch. Tierärztl. Wochenschr. 110:83-89.

De la Fuente, J., M. I. Salazar, M. Ibáñez and E. González de Chavarri. 2004. Effects of season and stocking density during transport on live weight and biochemical measurements of stress, dehydration and injury of rabbits at time of slaughter. J. Anim. Sci. 78:285-292.

EFSA (European Food Safety Authority). 2004. Opinion of the scientific panel on animal health and welfare on a request from the commission related to the welfare of animals during transport. Question number: EFSA-Q-2003-094. EFSA J. 44:136.

EFSA. 2011. Scientific opinion concerning the welfare of animals during transport EFSA panel on animal health and welfare (AHAW). EFSA J. 9:1966.

Fazio, E. and A. Ferlazzo. 2003. Evaluation of stress during transport. Vet. Res. Commun. 27:519-524. 
Garbus, J., B. Highman and P. D. Altland. 1967. Alterations in serum enzymes and isoenzymes in various species induced by epinephrine. Comp. Biochem. Physiol. 22:507-516.

Knowles, T. G. and P. D. Warriss. 2000. Stress physiology of animals during transport. In: Livestock Handling and Transport (Ed. T. Grandin). 2nd ed. pp. 385-407. Cambridge, MA: CABI Publishing.

Lambertini, L., G. Vignola, A. Badiani, G. Zaghini and A. Formigoni. 2006. The effect of journey time and stocking density during transport on carcass and meat quality in rabbits. Meat Sci. 72:641-646.

Liste, M. G., G. A. María, S. García-Belenguer, G. Chacón, P. Gazzola and M. Villarroel. 2008. The effect of transport time, season and position on the truck on stress response in rabbits. World Rabbit Sci. 16:229-235.

Manjoo, M., F. J. Burger and A. J. Kielblock. 1985. A relationship between heat load and plasma enzyme concentration. J. Therm. Biol. 10:221-225.

Marai, I. F. M. and A. A. Rashwan. 2004. Rabbits behavioural response to climatic and managerial conditions - a review. Arch. Tierz. Dummerstorf. 47:469-482.

Mazzone, G., G. Vignola, M. Giammaco, A. C. Manetta and L. Lambertini. 2010. Effect of loading on rabbit welfare and meat quality. Meat Sci. 8:33-39.

Melillo, A. 2007. Rabbit clinical pathology. J. Exotic Pet Med. 16:135-145.

Minka, N. S. and J. O. Ayo. 2009. Physiological responses of food animals to road transportation stress. Afr. J. Biotechnol. 8:7415-7427.

Muir, W. 2004. Recognizing and treating pain in horses. In Equine internal medicine, $2^{\text {nd }}$ edition (Ed. S. M. Reed, W. M. Bayly and D. C. Sellon), pp. 1529-1541. Saunders, St Louis, MO, USA.

Nemec Svete, A., N. Čebulj-Kadunc, R. Frangež and P. Kruljc. 2012. Serum cortisol and haematological, biochemical and antioxidant enzyme variables in horse blood sampled in a slaughterhouse lairage, immediately before stunning and during exsanguination. Animal 6:1300-1306.
Pérez, M. P., J. Palacio, M. P. Santolaria, M. C. Aceña, G. Chacón, M. Gascón, J. H. Calvo, P. Zaragoza, J. A. Beltran and S. Garc1'a-Belenguer. 2002. Effect of transport time on welfare and meat quality in pigs. Meat Sci. 61:425-433.

Sabuncuoglu, N., O. Coban, E. Lacin, Z. G. Ceylan, D. Ozdemir and A. Ozkan. 2011. Effect of pre-slaughter environment on some physiological parameters and meat quality in New Zealand rabbits (Oryctolagus cuniculus). Trop. Anim. Health Prod. 43:515-519.

Shaw, D. F. and K. R. Tume. 1992. The assessment of preslaughter treatments of livestock by measurement of plasma constituents: A review of recent work. Meat Sci. 32:311-329.

Terlouw, E. M. C., C. Arnould, B. Auperin, C. Berri, E. Le BihanDuval, V. Deiss, F. Lefevre, B. J. Lensink and L. Mounier. 2008. Pre-slaughter conditions, animal stress and welfare: current status and possible future research. Animal 2:15011517.

Vignola, G., M. Giammarco, G. Mazzone, G. Angelozzi and L. Lambertini. 2008. Effects of loading method and crate position on the truck on some stress indicators in rabbits transported to the slaughterhouse. In 9th World Rabbit Congress - June 10-13, 2008 - Verona - Italy. Ethology and Welfare, pp. 1257-1262.

von Borell, E. H. 2001. The biology of stress and its application to livestock housing and transportation assessment. J. Anim. Sci. 79:260-267.

Warris, P. D. 2000. Meat science. An Introductory text book. Chapter 10. CABI Publishing, UK.

Zulkifli, I., B. Norbaiyah, Y. W. Cheah, A. F. Soleimani, A. Q. Sazili, Y. M. Goh and M. A. Rajion. 2010a. A note on heat shock protein 70 expression in goats subjected to road transportation under hot, humid tropical conditions. Animal 4: 973-976.

Zulkifli, I., N. Bahyuddin, C. Y. Wai, A. S. Farjam, A. Q. Sazili, M. A. Rajion and Y. M. Goh. 2010b. Physiological responses in goats subjected to road transportation under the hot, humid tropical conditions. Int. J. Agric. Biol. 12:840-844. 